\title{
Effect of Different Level of N P K and Biochar on Soil Physico-chemical Properties and Yield Attribute of Black Gram (Vigna mungo L.) var KPU 07-08
}

\author{
Vivek Sehra*, Tarence Thomas and Arun Alfred David
}

Department of Soil Science and Agricultural Chemistry, Naini Agricultural Institute (NAI), Sam Higginbottom University of Agriculture Technology and Sciences, Prayagraj, 211007 U.P. India

*Corresponding author

\section{A B S T R A C T}

\section{Keywords}

Blackgram,

Soil, Urea, SSP, Biochar etc.

\section{Article Info}

Accepted:

20 July 2020

Available Online:

10 August 2020
An experiment was conducted on "Effect of different level of N P K and Biochar on Soil Physico-chemical properties and Yield Attribute of Black gram (Vigna mungo L.) Var. KPU 07-08” during Rabi season 2019-20 at the Research farm Department of Soil Science and Agricultural Chemistry, Naini Agriculture Institute, SHUATS, Prayagraj. The design applied was 3x3 randomized block design having three factors with three levels of NPK @ 0,50 , and $100 \% \mathrm{ha}^{-1}$, three levels of Biochar @ 0, 50 and 100\% ha ${ }^{-1}$ respectively. The result obtained with treatment $\mathrm{T}_{8^{-}}$[N P K @ $100 \%+$ Biochar @ 100\%] that showed the highest yield regarding, gave the best results with respect to plant height $60.10 \mathrm{~cm}$, number of leaves plant ${ }^{-1} 34.00$, No. of pod plant ${ }^{-1} 38.77$, it gave highest yield $13.05 \mathrm{q} \mathrm{ha}^{-1}$ Biochar

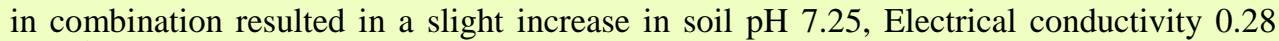
$\mathrm{dSm}^{-1}$. In post-harvest soil of NPK fertilizers observations were resulted in significant increase in Organic carbon $0.79 \%$, Particle density $2.64 \mathrm{Mg} \mathrm{m}^{-3}$, Bulk density $1.10 \mathrm{Mg} \mathrm{m}^{-}$ ${ }^{3}$, Pore space $58.33 \%$ and available $\mathrm{N} 340.23 \mathrm{kgha}^{-1}, \mathrm{P} 35.85 \mathrm{~kg} \mathrm{ha}^{-1}, \mathrm{~K} 206.64 \mathrm{~kg} \mathrm{ha}^{-1}$, significant increase in case of Nitrogen $\left(\mathrm{kg} \mathrm{ha}^{-1}\right)$, Phosphorus $\left(\mathrm{kg} \mathrm{ha}^{-1}\right)$, Potassium $\left(\mathrm{kg} \mathrm{ha}^{-1}\right)$ was found to be significant among other treatments in Black gram cultivation and soil quality improvement. It was also revealed that the application of N P K with Biochar was excellent source for fertilization than fertilizers.

\section{Introduction}

Urdbean (Vigna mungo L. Hepper) is among the major pulses grown throughout the country during both in summer and rainy season. Pulses are the main source of protein particularly for vegetarians and contribute about $14 \%$ of the total protein of average Indian diet. It is a self-pollinated leguminous crop containing $24 \%$ protein, $60 \%$ carbohydrate, $1.4 \%$ fat, $3.2 \%$ minerals, $0.9 \%$ fibre, $154 \mathrm{mg}$ calcium, $385 \mathrm{mg}$ phosphorus, $9.1 \mathrm{mg}$ iron and small amount of vitamin Bcomplex. Being a short duration crop, it fits well in various multiple and intercropping systems. After removing pods, its plant may be used as good quality green or dry fodder or green manure. Being a legume, it also 
enriches soil by fixing atmospheric nitrogen. India currently represents the largest producer of black gram accounting for more than $70 \%$ of the global production. India is followed by Myanmar and Pakistan. In India during kharif 2019-20, area covered under black gram is 37.52 lakh ha as against 38.18 lakh ha in last year. The states of Madhya Pradesh (16.50 lakh ha), Uttar Pradesh (7.01 lakh ha), Rajasthan (4.56 lakh ha), Maharashtra (2.87 lakh ha), Karnataka (0.687 lakh ha) and Andhra Pradesh (0.11 lakh ha) are the major producers of black gram in India during Kharif. (Directorate of Economics and Statistics (DES), $* 4^{\text {th }}$ Advance Estimates (2019-20). It can be grown on all type of soils ranging from sandy loam to heavy clay except alkaline and saline soils. However, it does well on heavier soils such as black cotton soils which retain higher moisture for longer time (Markam et al., 2017).

Soil is a medium for plant growth. Crop production is based largely on soils. Some of the soil properties affecting plant growth include: soil texture (coarse fine), aggregate size, porosity, aeration (permeability), and water holding capacity, $\mathrm{pH}$, bulk density, particle density. The rate of water movement into the soil (infiltration) is influenced by its texture, physical condition (soil structure and tilth), and the amount of vegetative cover on the soil surface.

Organic matter tends to increase the ability of all soils to retain water, and also increases infiltration rates of fine textured soils. Bulk density reflects the soil's ability to function for structural support, water and solute movement, and soil aeration. Soil $\mathrm{pH}$ directly affects the solubility of many of the nutrients in the soil needed for proper plant growth and development. As such, it is also a useful tool in making management decisions concerning the type of plants suitable for location, the possible need to modify soil $\mathrm{pH}$ (either up or down), and a rough indicator of the plant availability of nutrients in the soil.

Urdbean is capable of fixing atmospheric nitrogen, it responds to small quantity of nitrogenous fertilizers applied as starter dose. Application of $15-20 \mathrm{Kg} \mathrm{N}$ ha $^{-1}$ has been found optimum to get better response. Application of higher dose of nitrogen may reduce nodule number and nodule growth and thus adversely affect the nitrogen fixation capacity. Nitrogen is an important nutrient for all crops. It increases yield nutrition also increases the protein content. Deficient plants may have stunted growth and develop yellowgreen colour. It accelerates photosynthetic behaviour of green plants as well as growth and development of living tissues specially tiller count in cereals (Azadi et al., 2013). Phosphorus is the second most important nutrient that must be added to the soil to maintain plant growth and sustain crop yield. It stimulates early root development and growth and there by helps to establish seedlings quickly. Large quantities of Phosphorus are found in seed and fruit and it is considered essential for seed formation. It enhances the activity of rhizobia and increased the formation of root nodules. Thus, it helps in fixing more of atmosphere nitrogen in root nodules (Patil et al., 2011). Potassium is one of the seventeen elements which are essential for growth and development of plants. Potassium is required for improving the yield and quality of different crops because of its effect on photosynthesis, water use efficiency and plant tolerance to diseases, drought and cold as well for making the balance between protein and carbohydrates (Singh et al., 2008). Biochar is charcoal used as a soil amendment for both carbon sequestration and soil health benefits. Biochar is stable solid, rice in carbon and can endure in soil for thousands of years. Like most charcoal, it is made from biomass via pyrolysis it has the potential to help mitigate 
global warming and climate change. It results from processes related to pyrogenic carbon capture and storage (PyCCS). Biochar may increase soil fertility of acidic soils, increase agricultural productivity, and provide protection against some foliar and soil-borne diseases. The properties of biochar can be characterized in several respects, including the proximate and elemental composition, $\mathrm{pH}$ value, porosity etc, which correlate with different biochar properties. The atomic ratios of biochar, including $\mathrm{H} / \mathrm{C}$ and $\mathrm{O} / \mathrm{C}$, correlate with the biochar properties that are relevant to the organic content such as polarity and automaticity the carbonization process, both the $\mathrm{H} / \mathrm{C}$ and $\mathrm{O} / \mathrm{C}$ ratio (Lehmann et al., 2006). Biochar may help improve soil quality includes: Enhancing soil structure, increasing water retention and aggregation, decreasing acidity, reducing nitrous oxide emissions, improving porosity, regulating nitrogen leaching, improving EC and improving microbial properties(Cantrell et al., 2012). Properties of Biochar and their composition: $\mathrm{pH}=9.90, \mathrm{EC}=3.53 \mathrm{dSm}^{-1}$, B.D. $=0.19 \mathrm{Mgm}^{-}$ ${ }^{3}$, P.D. $=0.58 \mathrm{Mgm}^{-3}$, W.H.C. $=58.5 \%, \mathrm{Zn}=$ $157 \mathrm{mgkg}^{-1}, \mathrm{Mn}=214 \mathrm{mgkg}^{-1}, \mathrm{Cu}=54$ $\mathrm{mgkg}^{-1}, \mathrm{Co}=3.43 \mathrm{mgkg}^{-1}, \mathrm{Ni}=17.2 \mathrm{mgkg}^{-1}$, $\mathrm{Pb}=45.5 \mathrm{mgkg}^{-1}, \mathrm{Cd}=1.84 \mathrm{mgkg}^{-1}, \mathrm{P}=$ $0.09 \%, \mathrm{~K}=3.22 \%, \mathrm{Na}=0.99 \%, \mathrm{Fe}=0.28 \%$, $\mathrm{Ca}=0.38 \%, \mathrm{Mg}=0.25 \%, \mathrm{Al}=1.83 \%($ Bird et al., 2011).

In India, about 435.98 million tons of agroresidues are produced every year, out of which 313.62 million tons are surplus. These residues are either partially utilized orunutilized due to various constraints. Efficient use of biomass by converting it as a useful source of soil amendment/nutrients is one way to manage soil health and fertility. One of the approaches for efficient utilization of biomass involves carbonization of biomass to highly stable carbon compound known as biochar and its use as a soil amendment. Use of biochar in agricultural systems is one viable option that can enhance natural rates of carbon sequestration in the soil, reduce farm waste and improve the soil quality IARI (2012).

\section{Materials and Methods}

The experiment was conducted at research farm of department of Soil Science and Agricultural Chemistry which is situated six $\mathrm{km}$ away from Prayagraj city on the right bank of Yamuna river, the experimental site is located in the sub-tropical region with $25^{\circ} 2423$ "N latitude, $81^{0} 50$ ' $38^{\prime \prime}$ Elongitude and at an altitude of $98 \mathrm{~m}$ above mean sea level. The area of Prayagraj district comes under subtropical belt in the South east of Uttar Pradesh, which experience extremely hot summer and fairly cold winter. The maximum temperature of the location reaches up to 46 ${ }^{0} \mathrm{C}-48{ }^{0} \mathrm{C}$ and seldom falls as low as $4^{0} \mathrm{C}-5^{0} \mathrm{C}$. The relative humidity ranges between 20 to 94 percent. The average rainfall in this area is around $1013.4 \mathrm{~mm}$ annually. The soil of experimental area falls in order of Inceptisol. The soil samples were randomly collected from five different sites in the experiment plot prior to tillage operation from a depth of 0-15 $\mathrm{cm}$. The size of the soil sample was reduced by conning and quartering the composites soil sample and was air dried passed through a 2 $\mathrm{mm}$ sieve for preparing the sample for physical and chemical analysis. The KPU 0708 (Pratap Urd-1) is a high yielding cultivar of blackgram. It was released from Agriculture Research Station, Kota for rainfed conditions and notified in the year 2013. The characteristic of KPU 07-08(Pratap urd-1)is appropriate $10-11 \mathrm{q} \mathrm{ha}^{-1}$ yield and it is to moisture stress, moderately resistant to yellow mosaic virus, leaf crinkle, anthracnose, bacterial leaf blight.

\section{Results and Discussion}

As depicted in tables no. $4 \& 5$ which is representing data of physical and chemical properties of soil sample after harvesting of 
black gram respectively having maximum Bulk density $\left(\mathrm{Mg} \mathrm{m}^{-3}\right)$ of soil was recorded $1.26 \mathrm{Mg} \mathrm{m}^{-3}$ in treatment $\mathrm{T}_{0}$ (control) and minimum Bulk density $\left(\mathrm{Mg} \mathrm{m}^{-3}\right)$ of soil was recorded $1.10 \mathrm{Mg} \mathrm{m}^{-3}$ in treatment $\mathrm{T}_{8}\left(\mathrm{~N}_{20} \mathrm{P}_{40}\right.$ $\mathrm{K}_{40}+$ and $100 \%$ Biochar). Similar results were also reported by (Amruta et al., 2016). Particle density $\left(\mathrm{Mg} \mathrm{m}^{-3}\right)$ of soil was recorded $2.64 \mathrm{Mg} \mathrm{m}^{-3}$ in treatment $\mathrm{T}_{8}\left(\mathrm{~N}_{20} \mathrm{P}_{40} \mathrm{~K}_{40}+\right.$ and $100 \%$ Biochar) and minimum Particle density $\left(\mathrm{Mg} \mathrm{m}^{-3}\right)$ of soil was recorded 2.35 $\mathrm{Mg} \mathrm{m}^{-3}$ in treatment $\mathrm{T}_{0}$ (control). Similar results were also reported by (Sarvanan et al., 2013). Soil pore space was recorded $58.33 \%$ in treatment $\mathrm{T}_{8}\left(\mathrm{~N}_{20} \mathrm{P}_{40} \mathrm{~K}_{40}+\right.$ and $100 \%$ Biochar) and minimum soil pore space was recorded $46.38 \%$ in treatment $\mathrm{T}_{0}$ (Control). Similar results were also reported by (Tiwari and Kumar 2009). Soil pH was recorded 7.25 in treatment $\mathrm{T}_{0}$ (control) and minimum soil pH was recorded 6.75 in treatment $\mathrm{T}_{8}\left(\mathrm{~N}_{20} \mathrm{P}_{40}\right.$ $\mathrm{K}_{40}+$ and $100 \%$ Biochar). Similar results were also reported by (Takase et al., 2011). EC $\left.(\mathrm{dS} \mathrm{m})^{-1}\right)$ of soil was recorded $0.28 \mathrm{dS} \mathrm{m}^{-1}$ in treatment $\mathrm{T}_{8}\left(\mathrm{~N}_{20} \mathrm{P}_{40} \mathrm{~K}_{40}+\right.$ and $100 \%$ Biochar) and minimum EC ( $\left.\mathrm{dS} \mathrm{m}^{-1}\right)$ of soil was recorded $0.16 \mathrm{dS} \mathrm{m}^{-1}$ in treatment $\mathrm{T}_{0}$ (control). Similar results were also reported by (Akbari et al., 2010). The maximum \% Organic carbon in soil was recorded $0.79 \%$ in treatment $\mathrm{T}_{8}\left(\mathrm{~N}_{20} \mathrm{P}_{40} \mathrm{~K}_{40}+\right.$ and Biochar 100 $\%)$ which was significantly higher than any other treatment combination and the minimum \% Organic carbon in soil was recorded $0.58 \%$ in treatment $\mathrm{T}_{0}$ (control).Similar findings were recorded by (Jat et al., 2012). The highest available Nitrogen in soil was recorded $340.23(\mathrm{Kg}$ $\left.h^{-1}\right)$ in treatment $\mathrm{T}_{8}\left(\mathrm{~N}_{20} \mathrm{P}_{40} \mathrm{~K}_{40}+\right.$ and Biochar $100 \%$ ) which was significantly higher than any other treatment combination and the minimum available Nitrogen in soil was recorded $292.50\left(\mathrm{Kg} \mathrm{ha}^{-1}\right)$ in treatment $\mathrm{T}_{0}$ (control). Similar findings were also recorded by (Biswash et al., 2014), (Amrita et al., 2017). The highest available Phosphorus in soil was recorded $35.85\left(\mathrm{Kg} \mathrm{ha}^{-1}\right)$ in treatment $\mathrm{T}_{8}\left(\mathrm{~N}_{20} \mathrm{P}_{40} \mathrm{~K}_{40}+\right.$ and Biochar $\left.100 \%\right)$ which was significantly higher than any other treatment combination and the minimum available Phosphorus in soil was recorded $25.50\left(\mathrm{Kg} \mathrm{ha}{ }^{-1}\right)$ in treatment $\mathrm{T}_{0}$ (control).Similar findings were also recorded by(Datt et al.,2013), (Tomar et al., 2013). The highest available Potassium in soil was recorded $206.64\left(\mathrm{Kg} \mathrm{ha}^{-1}\right)$ in treatment $\mathrm{T}_{8}$ $\left(\mathrm{N}_{20} \mathrm{P}_{40} \mathrm{~K}_{40}+\right.$ and Biochar $\left.100 \%\right)$ which was significantly higher than any other treatment combination and the minimum available Potassium in soil was recorded $134.95(\mathrm{Kg}$ $\mathrm{ha}^{-1}$ ) in treatment $\mathrm{T}_{0}$ (control). Similar findings were also recorded by (Owla et al., 2007) (Fig. 1 and 2; Table 1-5).

Table.1 Treatment combinations

\begin{tabular}{|c|c|l|}
\hline S. No. & Symbol & \multicolumn{1}{c|}{ Description } \\
\hline $\mathbf{1 .}$ & $\mathrm{T}_{0}-\mathrm{L}_{0} \mathrm{~B}_{0}$ & [ @ 0\% N P K + @ 0 \% Biochar] \\
$\mathbf{2 .}$ & $\mathrm{T}_{1}-\mathrm{L}_{0} \mathrm{~B}_{1}$ & [ @ 0\% N P K + @ 50\% Biochar] \\
$\mathbf{3 .}$ & $\mathrm{T}_{2}-\mathrm{L}_{0} \mathrm{~B}_{2}$ & [ @ 0\% N P K + @ 100\% Biochar] \\
$\mathbf{4 .}$ & $\mathrm{T}_{3}-\mathrm{L}_{1} \mathrm{~B}_{0}$ & [ @ 50\% N P K + @ 0\% Biochar] \\
$\mathbf{5 .}$ & $\mathrm{T}_{4}-\mathrm{L}_{1} \mathrm{~B}_{1}$ & [ @ 50\% N P K + @ 50\% Biochar] \\
$\mathbf{6 .}$ & $\mathrm{T}_{5}-\mathrm{L}_{1} \mathrm{~B}_{2}$ & [ @ 50\% N P K + @ 100\% Biochar] \\
$\mathbf{7 .}$ & $\mathrm{T}_{6}-\mathrm{L}_{2} \mathrm{~B}_{0}$ & [ @ 100\% N P K + @ 0 \% Biochar] \\
$\mathbf{8 .}$ & $\mathrm{T}_{7}-\mathrm{L}_{2} \mathrm{~B}_{1}$ & [ @ 100\% N P K + @ 50\% Biochar] \\
$\mathbf{9 .}$ & $\mathrm{T}_{8}-\mathrm{L}_{2} \mathrm{~B}_{2}$ & [ @ 100\% N P K+ @ 100\% Biochar] \\
\hline
\end{tabular}


Table.2 Physical analysis of pre sowing soil samples

\begin{tabular}{|c|c|c|}
\hline Particulars & Results & Method employed \\
\hline Sand $(\%)$ & 62.71 & \multirow{4}{*}{$\begin{array}{l}\text { Bouyoucos Hydrometer } \\
\text { (1927) }\end{array}$} \\
\hline Silt (\%) & 23.10 & \\
\hline Clay $(\%)$ & 14.19 & \\
\hline Textural class & Sandy loam & \\
\hline Soil Colour & & \multirow{3}{*}{ Munsell Colour Chart (1971) } \\
\hline Dry Soil & Pale brown Colour & \\
\hline Wet Soil & Olive brown Colour & \\
\hline Bulk density $\left(\mathrm{Mg} \mathrm{m}^{-3}\right)$ & 1.23 & \multirow{3}{*}{$\begin{array}{l}\text { Graduated Measuring } \\
\text { Cylinder (Muthuvel et al.,1992) } \\
\text { Graduated Measuring } \\
\text { Cylinder (Muthuvel et al.,1992) }\end{array}$} \\
\hline Particle density $\left(\mathrm{Mg} \mathrm{m}^{-3}\right)$ & 2.37 & \\
\hline Pore Space $(\%)$ & 47.53 & \\
\hline
\end{tabular}

Table. 3 Chemical analysis of pre sowing soil samples

\begin{tabular}{|c|c|c|}
\hline Parameters & Method employed & Results \\
\hline Soil pH (1:2) & $\begin{array}{l}\text { Glass electrode, } \mathrm{pH} \text { meter } \\
\text { (Jackson, 1958) }\end{array}$ & 7.58 \\
\hline Soil EC $\left(\mathrm{dSm}^{-1}\right)$ & $\begin{array}{l}\text { EC meter (Conductivity } \\
\text { Bridge)(Wilcox, 1950) }\end{array}$ & 0.177 \\
\hline Organic Carbon (\%) & $\begin{array}{l}\text { Wet Oxidation Method } \\
\text { (Walkley and Black's, 1947) }\end{array}$ & 0.45 \\
\hline Available Nitrogen $\left(\mathrm{Kg} \mathrm{ha}^{-1}\right)$ & $\begin{array}{l}\text { Kjeldhal Method } \\
\text { (Subbaih and Asija, 1956) }\end{array}$ & 238.21 \\
\hline Available Phosphorus $\left(\mathrm{Kg} \mathrm{ha}^{-1}\right)$ & $\begin{array}{l}\text { Colorimetric method } \\
\text { (Olsen et al., 1954) }\end{array}$ & 20.73 \\
\hline Available Potassium $\left(\mathrm{Kg} \mathrm{ha}^{-1}\right)$ & $\begin{array}{l}\text { Flame photometric method } \\
\text { (Toth and Price, 1949) }\end{array}$ & 127.65 \\
\hline
\end{tabular}

Table.4 Physical properties of soil sample after harvesting of Black gram

\begin{tabular}{|c|c|c|c|}
\hline Treatment & $\begin{array}{c}\text { Bulk Density } \\
\left(\mathbf{M g ~ m}^{-\mathbf{3}}\right)\end{array}$ & $\begin{array}{c}\text { Particle Density } \\
\left(\mathbf{M g ~ m}^{-\mathbf{3}}\right)\end{array}$ & $\begin{array}{c}\text { Pore space } \\
(\mathbf{\%})\end{array}$ \\
\hline $\mathbf{T}_{\mathbf{0}}$ & 1.26 & 2.35 & 46.38 \\
\hline $\mathbf{T}_{\mathbf{1}}$ & 1.23 & 2.38 & 48.31 \\
\hline $\mathbf{T}_{\mathbf{2}}$ & 1.22 & 2.42 & 49.58 \\
\hline $\mathbf{T}_{\mathbf{3}}$ & 1.19 & 2.48 & 52.01 \\
\hline $\mathbf{T}_{\mathbf{4}}$ & 1.16 & 2.52 & 53.96 \\
\hline $\mathbf{T}_{\mathbf{5}}$ & 1.15 & 2.54 & 54.72 \\
\hline $\mathbf{T}_{\mathbf{6}}$ & 1.13 & 2.56 & 55.85 \\
\hline $\mathbf{T}_{\mathbf{7}}$ & 1.11 & 2.58 & 56.97 \\
\hline $\mathbf{T}_{\mathbf{8}}$ & 1.10 & 2.64 & 58.33 \\
\hline $\mathbf{F}-\mathbf{t e s t}$ & $\mathrm{NS}$ & $\mathrm{NS}$ & $\mathrm{S}$ \\
\hline S. $\mathbf{E m} \pm$ & 0.05 & 0.33 & 1.38 \\
\hline C.D & 0.11 & 0.69 & 2.94 \\
\hline
\end{tabular}


Table.5 Chemical properties of soil sample after harvesting of Black gram

\begin{tabular}{|c|c|c|c|c|c|c|}
\hline Treatments & pH & $\begin{array}{c}\mathrm{EC} \\
\left(\mathrm{dSm}^{-1}\right)\end{array}$ & $\begin{array}{c}\text { Organic } \\
\text { carbon }(\%)\end{array}$ & $\begin{array}{c}\text { Available } \\
\text { Nitrogen }\left(\mathrm{Kg} \mathrm{ha}^{-1}\right)\end{array}$ & $\begin{array}{c}\text { Available } \\
\text { Phosphorus }\left(\mathrm{Kg} \mathrm{ha}^{-1}\right)\end{array}$ & $\begin{array}{c}\text { Available } \\
\text { potassium } \\
\left(\mathrm{Kg} \mathrm{ha}^{-1}\right)\end{array}$ \\
\hline $\mathbf{T}_{0}$ & 7.25 & 0.16 & 0.58 & 292.50 & 25.50 & 134.95 \\
\hline $\mathbf{T}_{1}$ & 7.25 & 0.17 & 0.60 & 303.83 & 27.15 & 145.18 \\
\hline $\mathbf{T}_{2}$ & 7.05 & 0.19 & 0.68 & 304.88 & 27.85 & 155.43 \\
\hline $\mathbf{T}_{3}$ & 7.04 & 0.20 & 0.65 & 312.22 & 28.95 & 156.27 \\
\hline $\mathbf{T}_{4}$ & 7.00 & 0.22 & 0.66 & 314.31 & 30.05 & 169.45 \\
\hline$T_{5}$ & 6.95 & 0.22 & 0.70 & 320.60 & 30.75 & 172.45 \\
\hline$T_{6}$ & 6.95 & 0.23 & 0.69 & 322.65 & 30.95 & 191.65 \\
\hline $\mathbf{T}_{7}$ & 6.85 & 0.25 & 0.77 & 328.93 & 34.54 & 199.28 \\
\hline $\mathbf{T}_{8}$ & 6.75 & 0.28 & 0.79 & 340.23 & 35.85 & 206.64 \\
\hline F-test & $\mathrm{S}$ & NS & $\mathrm{S}$ & S & $\mathrm{S}$ & S \\
\hline S. Em. \pm & 0.06 & 0.28 & 0.01 & 3.24 & 0.56 & 7.78 \\
\hline $\begin{array}{c}\text { C.D. } \\
(\mathbf{P}=\mathbf{0 . 0 5})\end{array}$ & 0.12 & 0.06 & 0.03 & 6.87 & 1.18 & 16.49 \\
\hline
\end{tabular}

Fig.1 Physical properties of soil sample after harvesting of Black gram

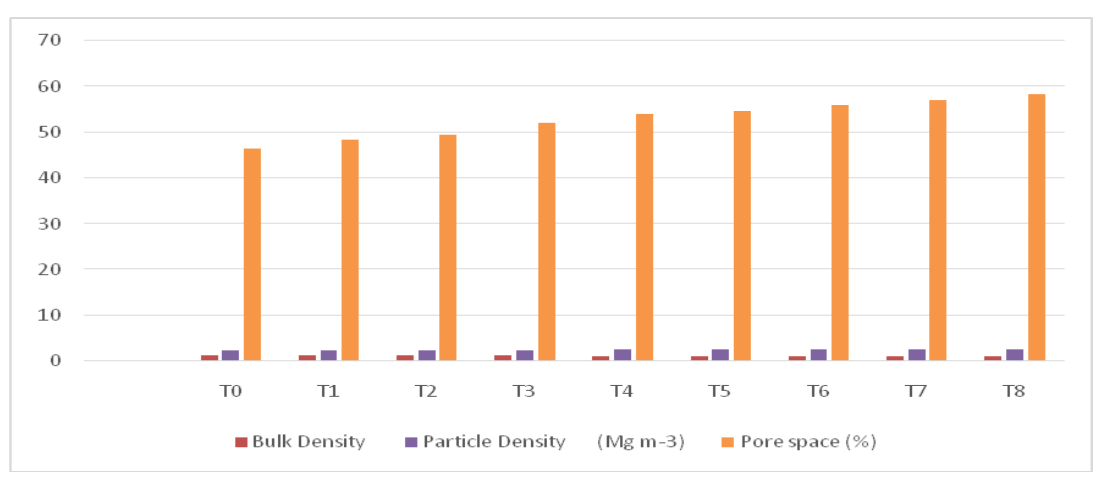

Fig.2 Chemical properties of soil sample after harvesting of Black gram

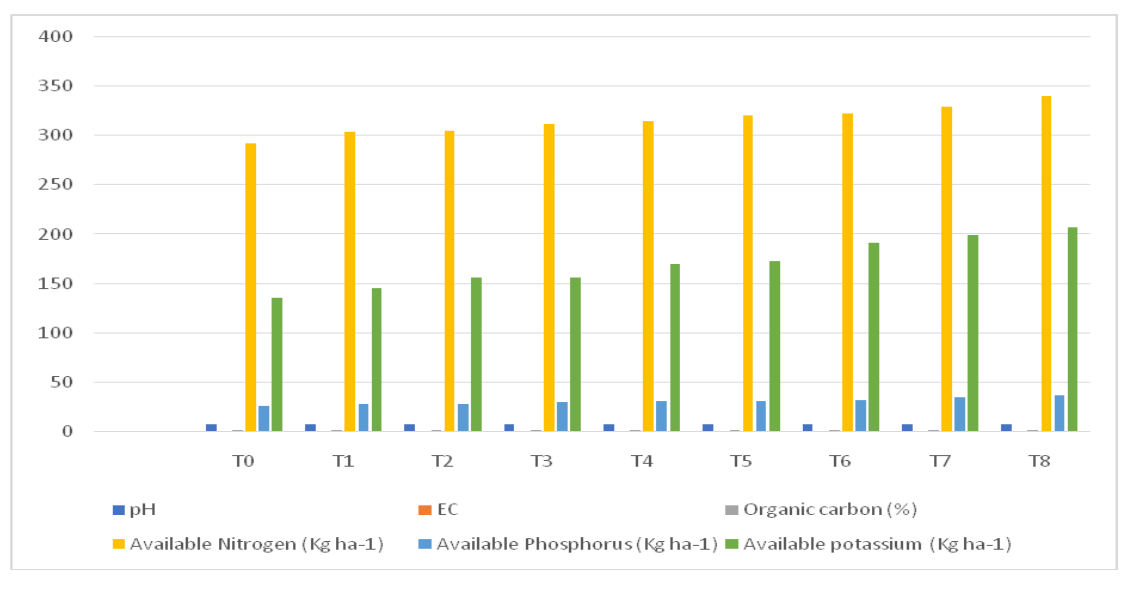


The salient findings of the present investigation are summarized as follows.

The soil texture observed was sandy loamy. The soil colour in dry condition was light yellowish brown and wet condition was olive brown. The soil $\mathrm{pH}$ was 7.25 and Bulk density $1.10 \mathrm{Mg} \mathrm{m}^{-3}$, has resulted due to the application of NPK and Biochar while Particle density $2.64 \mathrm{Mg} \mathrm{m}^{-3}$, Pore space $58.33 \%$, Electrical conductivity0.28 $\mathrm{dSm}^{-}$ ${ }^{1}$,Organic carbon $0.79 \%$, respectively Nitrogen $340.23 \mathrm{~kg} \mathrm{ha}^{-1}$, Phosphorus $35.85 \mathrm{~kg}$ $\mathrm{ha}^{-1}$ and Potassium $206.64 \mathrm{~kg} \mathrm{ha}{ }^{-1}$, has increase by the application of NPK and Biochar. The best treatment was $\mathrm{T}_{8}-\mathrm{L}_{2} \mathrm{~B}_{2}$ [@ $100 \%$ NPK+ @ 100\% Biochar]. In post soil the important parameter on chemical properties on black gram crop different treatment of NPK and Biochar, percentage pore space, $\mathrm{pH}$, organic carbon (\%),nitrogen $\left(\mathrm{kg} \mathrm{ha}^{-1}\right)$, phosphorus $\left(\mathrm{kg} \mathrm{ha}^{-1}\right)$, potassium ( $\mathrm{kg}$ $\mathrm{ha}^{-1}$ ) respectively were found significant and $\mathrm{EC}$ was found non-significant. $\mathrm{pH}$, organic carbon (\%), available nitrogen $\left(\mathrm{kg} \mathrm{ha}^{-1}\right)$, phosphorus $\left(\mathrm{kg} \mathrm{ha}^{-1}\right)$, and potassium $\left(\mathrm{kg} \mathrm{ha}^{-1}\right)$ was recorded as 7.25, 0.79, 340.23, 35.85, and 206.64 respectively.

It was concluded from trail that treatment $\mathrm{T}_{8}$ $\mathrm{L}_{2} \mathrm{~B}_{2}$ [@100\% NPK+ @ 100\% Biochar] gave the most significant findings in terms of soil properties and yield attributes of Black gram var. KPU 07-08, N P K and Biochar. Biochar increases soil organic matter content in soil, it's improve soil health and enhance the yield of Black gram.

\section{Acknowledgement}

I am grateful for ever-inspiring guidance, constant encouragement, keen interest, comments and constructive suggestions throughout the course of my studies and investigation, from, head of the department and staff, department of Soil Science and
Agricultural Chemistry, Sam Higginbottom University of Agriculture, Technology and Sciences, Prayagraj, Uttar Pradesh.

\section{References}

Akbari, K.N., Sutaria, G.S.; Vora, V.D.; Hirpara, D.S. and Padmani, D.R. (2010) Effect of periodical application of phosphorus with and without FYM on yield of groundnut on verticustochrepts under rainfed agriculture. Legume Research, 33: 64-66.

Amruta N., Devaraju, P. J., Mangalagowri, S. P., Kiran, Ranjitha, H. P. and Teli, K. (2016)Effect of integrated nutrient management and spacing on seed quality parameters of black gram cv. Lbg-625 (Rashmi) Journal of Applied and Natural Science, 8 (1): 340 -345.

Amrita M., Swaroop N., Thomas T. and Soman Singh Dhruw (2017) Effects of Different Levels of NPK and Molybdenum on Soil Physico chemical properties of Black gram (VignamungoL.) Var. Shekhar-2. 6(8) 1082-1088.

Azadi, E., Rafiee, M. and Hadis, N. (2013). The effect of different nitrogen levels on seed yield and morphological characteristic of mung bean in the climate condition of Khorramabad. Annals of Biological Research, 2013, 4 (2):51-55.

Bird, M.I., Wurster, C. M., Silva, P., Bass, A. M. and De Nye, R. (2011) Algalbiochar - production and properties. Bioresource Technology, 102: 1886 1891.

Biswash M. R., Rahman M. W., Haque M. M., Sharmin M. and Barua, R. (2014) Effect of Potassium and Vermicompost on the Growth, Yield and Nutrient Contents of Mung bean (BARI Mung 5). Open Science Journal of Bioscience and Bioengineering. 1, No. 3, 2014, pp. 
33-39.

Bouyoucos, G. J. (1927) The hydrometer as a new method for the mechanical analysis of soils. Soil Sci., 23: 393-395

Cantrell, K. B., Hunt, P. G., Uchimura, M. Novak, Z. N. and Ro, K. S. (2012) Impact of pyrolysis temperature and manure source on physico-chemical characteristics of biochar. Bioresource Technology107: 419- 428.

Directorate of Economics and Statistics (DES), *4thAdvance Estimates 201920.

Datt N, Sharma R. P., Sharma G. D. (2013) Effect of supplementary use of farmyard manure along with chemical fertilizers on productivity and nutrient uptake by vegetable pea (Pisum sativum var. arenes) and build-up of soil fertility in Lahaul Valley. Indian J. Agric. Sci. 73:266-268.

Greenfield Eco Solutions Pvt. Ltd. -Biochar used in the experiment was bought from Greenfield Eco Solutions Pvt. Ltd. 11/895, CHB, Nandavan Jodhpur, Rajasthan India (342001)

IARI (2012) Crop residues management with conservation agriculture: Potential, constraints and policy needs. Indian Agricultural Research Institute, New Delhi, $32 \mathrm{p}$.

Jackson, M.L. (1958) The pH was determined in 1:2 soil water suspensions using digital $\mathrm{pH}$ meter.

Jat, S. L., Prasad, K. and Parihar, C. M. (2012) Effect of organic manuring on productivity and economics of summer mung bean. Annals Agril. Res. (New Series), 33(1\&2): 17-20.

Lehmann, J., J. Gaunt and M. Rondon. (2006) Biochar sequestration in terrestrial ecosystem- A review. Mitigat. Adapt. Stra.Global Change. 11:395-419.

Liang, B., J. Lehmann, D. Solomon, J. Kinyangi, J. Grossman, B. O'Neill, J.O. Skjemstad, J. Thies, F.J. Luizão, J.
Petersen and E.G. Neves (2006) Black carbon increases cation exchange capacity in soils. Soil Sci. Soc. Am. J. 70:1719-1730

Markam, A., Narendra Swaroop, Tarence Thomas and Soman Singh Dhruw (2017) Effects of Different Levels of N P K and Molybdenum on Soil Physico Chemical Properties of Black Gram (Vignamungo L.) Var. Shekhar-2. Int. J. Curr. Microbial. App. Sci. 6(8): 10821088.

Munsell, A.H., ed. 12, (1971)A Color Notation. Baltimore, MD: MunsellColor Company. PP.- 65.

Muthuvel P., C. Udaysoorian, R. Natesan, P. P. Ramaswami, (1992)Introduction to Soil analysis, Tamil Nadu Agricultural University, Coimbatore-641002.

Olsen, S.R., Watanale, F. S., (1954)A method to determine a phosphorus adsorption measured by colorimetric method soil sci. soc. Am. J. 21, 144-149

Owla, R.L., Chavan, B.N. and Singh, U. 2007 Effect of plant densities and phosphorus levels on growth and yield of green gram (Vigna radiata). Annals of Agricultural Research 28(1): 95-97.

Patil, S.C., Jagtap, D.N. and Bhale, V.M. (2011) Effect of phosphorus and sulphur on growth and yield of moong bean. Internet J. Agric. Sci., 7(2): 348351.

Saravanan, P., Singh, S. K. and Kumar, I. (2013) Effect of organic manures and chemical fertilizers on the yield and macronutrient concentrations of green gram. International Journal of Pharmaceutical Science Invention ISSN (Online): 2319 - 6718, ISSN (Print): $2319-670 X$.

Singh, R.P., Bisen, J.S., Yadav, P.K., Singh, S.N., Singh, R. K. and Singh, J. (2008) Integrated use of sulphur and molybdenum on growth, yield and quality of black gram. Legume 
Research 31: 214-217.

Subbiah, B.V. and Asija (1956) A rapid procedure for estimation of available nitrogen in soils curr. Sci. 25:259

Steiner, C., W.G. Teixeira, J. Lehmann, T. Nehls, J. L.V. MaceDo and W. Zech. (2007) Long term effects of manure, charcoal and mineral fertilization on crop production and fertility on a highly weathered Central Amazonian upland soil. Plant. Soil. 291: 275-290.

Takase, M., Owusu, L. K. and Sekyere, J. D. (2011)The Effects Of Four Sources Of Irrigation Water On Soil Chemical And Physical Properties. Asian Journal of Plant Sciences; 10: 1, pp. 92-96.18.

Tiwari, D. and Kumar, K. (2009) Effect of biofertilizer and phosphorus level on growth, nodulation and yield of mung bean (In) International Conference on Grain Legumes: Quality Improvement, Value Addition and Trade held during,
14-16, February, 2009 at Indian Institute of Pulse Research, Kanpur.

Tomar, T. S., Kumar, S. and Tomar, S. (2013) Effects of plant density, nitrogen and phosphorus on black gram (Vignamungo L. hepper). Annals Agril. Res. (New Series) 34(4): 374-379.

Toth, S.J., A. L. Prince (1949)Estimation of cation exchange capacity and exchangeable calcium, potassium and sodium contents of soils by flame photometer techniques. Soil sci. 67, 439-445.

Walkley, A. and Black, I. A. (1947)Critical examination of rapid method for determining organic carbon in soils, effect of variance in digestion conditions and of inorganic soil constituents. Soil sci. pp. 632:251.

Wilcox (1950) Electrical conductivity. Am water work Assoc. J 42; pp. 77.

\section{How to cite this article:}

Vivek Sehra, Tarence Thomas and Arun Alfred David. 2020. Effect of Different Level of N P $\mathrm{K}$ and Biochar on Soil Physico-chemical Properties and Yield Attribute of Black Gram (Vigna mungo L.) var KPU 07-08. Int.J.Curr.Microbiol.App.Sci. 9(08): 2007-2015. doi: https://doi.org/10.20546/ijcmas.2020.908.229 